\title{
An Empirical Study on the Effect and Quality of Situational English Teaching
}

\author{
https://doi.org/10.3991/ijet.v16i21.26863 \\ Kun Liang( $\left.{ }^{\bowtie}\right)$, Yanan Hao, Jiangyong Zhao \\ Shijiazhuang University of Applied Technology, Shijiazhuang, China \\ liangkun84130@163.com
}

\begin{abstract}
This paper explores the quality and effect of Situational English Teaching (SET). The subjects are a few non-English majors from five colleges in a Chinese province. Taking college English course for example, a questionnaire survey was carried out to investigate the application state of SET in college English teaching. The survey shows that most college students are poor in English, and the traditional teaching mode cannot effectively improve students' English level. Hence, it is feasible to apply SET in college English class. Based on the survey results, a new English teaching mode was designed based on SET, and its application effect was investigated empirically. The empirical analysis shows that the SET-based new mode can boost students' learning interest and comprehensive use of English, and significantly improve the quality of English teaching. The research results enrich the evidence of SET, and promote the application of SET in college English class.
\end{abstract}

Keywords-situational English teaching (SET), English class, teaching effect, teaching quality, scene

\section{Introduction}

The reform of higher education is being pushed forward constantly in recent year in China, taking students as the center of higher education, cultivating students' sense, interest, and confidence of English language, and promoting students' comprehensive English language skills have become key issues in the teaching reform of English major and the inevitable development trend in the future [1]. However, most teachers are already accustomed to the traditional teaching mode and experience, in traditional textbooks, the content is too theoretical and dull, and the traditional classrooms couldn't provide a good English language environment for students, as a result, students can hardly see achievement in English learning, after a while, they gradually lose interest in English learning [2].

English major is a language application discipline, during English teaching, vocabularies, grammar, and sentence structures appear in the form of scenes [3]. SET is a teaching method derived from situational teaching, its advantage lies in the use of various teaching resources to create and restore real language scenes that are consistent with the teaching content, it enables students to merge into the scenes and have 
immediate experience, turns the dull and tedious English words and sentences into surrounding scenes, and allows students to learning knowledge from specific situations. Situational teaching can trigger students' interest in learning, deepen their cognition and understanding of English knowledge, enhance their comprehensive language use ability, and ultimately achieve the goal of English teaching and improve the quality of English class [4]. Foreign countries started earlier in the research of situational teaching, a representative one is the United Kingdom, British scholar Hornby emphasized the authenticity of the scenes in situational teaching and the rationality of this teaching method in his study [5]. Germany and Japan mainly apply situational teaching to mother tongue language teaching, but not all scholars hold a supportive attitude towards SET [6]. In China, drawing on the foreign experience, situational teaching has been extended to a certain extent by scholars based on the actual conditions in the country [7]. Chinese scholars have extended the application scope of situational teaching from basic education to all stages in higher education, and now situational teaching has been widely applied in many disciplines [8]. Moreover, Chinese scholars' research on situational teaching involves many aspects such as the concept, advantages, scene creation methods, and multimedia-assisted situational teaching, etc. [9], however, there're also a few problems with situational teaching in China, such as the created scenes are not real and not continuous enough $[10,11]$.

Based on the results of SET-related research, this paper attempts to construct a new English teaching mode based on SET, and explore its effect and quality, in the hopes of promoting the wide application of SET in college English teaching.

\section{SET in current college English teaching}

\subsection{Subjects and methodology}

Subjects are several non-English major teachers and students from 5 colleges in a Chinese province. Based on foreign and domestic research results concerning SET, this study designed two questionnaires to investigate the application of SET in current college English teaching, the questionnaires were divided into two parts: one for teachers, and one for students [12]. During the survey, 25 teacher questionnaires and 237 student questionnaires were distributed; wherein all returned teacher questionnaires were valid, and 228 returned student questionnaires were valid, the effective rates were $100 \%$ and $96.2 \%$, respectively. Figure 1 is a statistics of teacher titles. 


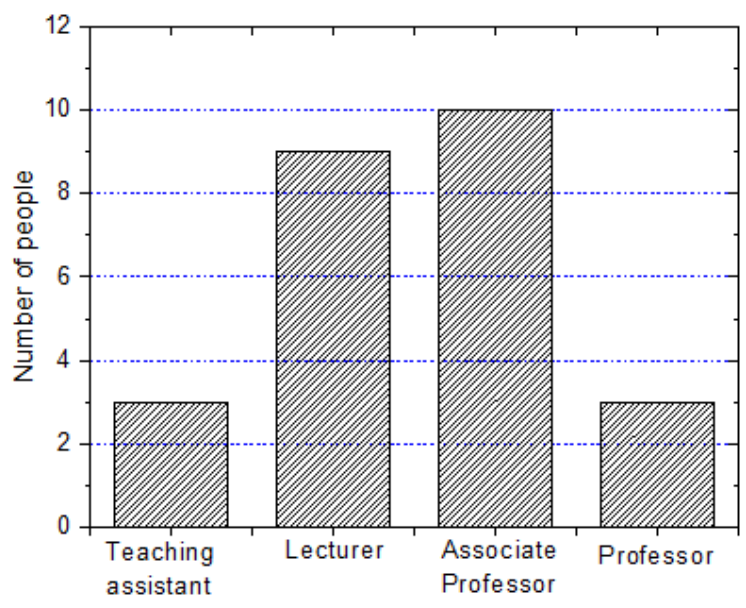

Fig. 1. Statistics of teacher titles

\subsection{Statistics and analysis}

Student questionnaire. College graduates should acquire good listening, speaking, reading, writing, and translation skills in English, so as to have a strong competitive advantage in employment. Figure 2 shows the survey results of the English proficiency of students evaluated by themselves, as can be seen from the figure, most of the students do not think highly of their English level, further investigation showed that there're two reasons for it, one is that the students' English test scores are relatively low, so they generally think their English proficiency is not good; the other reason is that during the teaching process, students are the audience in most cases, and they have not really exercised their English. Therefore, most students believe that their ability to use English in practice is poor.

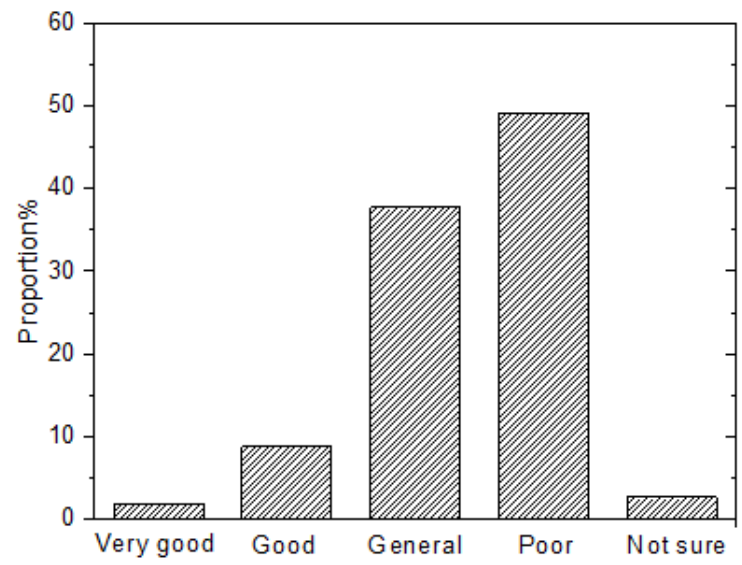

Fig. 2. Statistics of students' English proficiency 
Figure 3 shows the statistics on whether students think the teaching methods adopted by teachers are helpful for improving their comprehensive English ability. According to the figure, $31.6 \%$ of the students think that the teaching methods adopted by teachers are not very helpful or not helpful at all for improving their comprehensive English ability, these students think the teachers have only taught the basic language knowledge such as grammar and vocabulary, and there's no comprehensive application content in the class; however, $42.6 \%$ of the students consider the teaching methods to be helpful or very helpful, they believe the methods are conductive to consolidating the basic knowledge, which is the prerequisite for improving the comprehensive English ability.

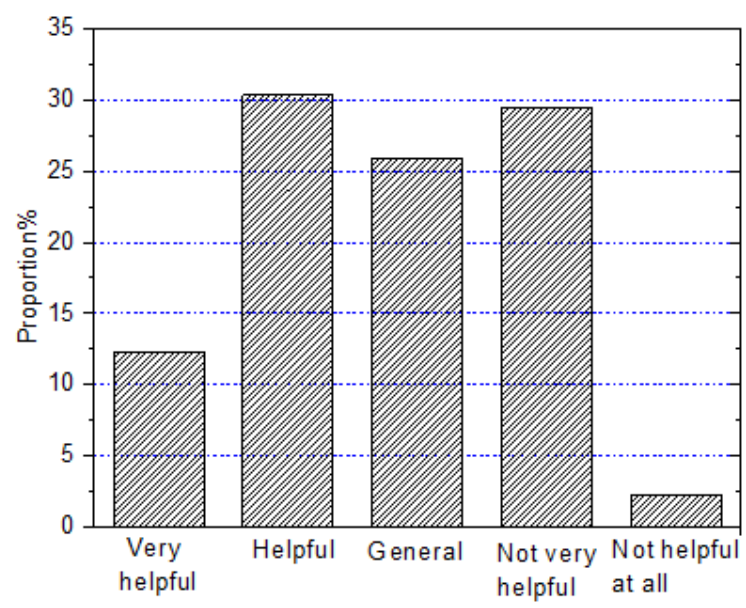

Fig. 3. Statistics on whether students think the teaching methods adopted by teachers are helpful for improving their comprehensive English ability

Table 1 shows the survey results of students' understanding and acceptance of SET, as can be read from the table, most students do not know much about SET, indicating that they seldom get in tough with SET, their cognition of SET only comes from its literal meaning. When students were asked about whether they are willing to try SET in their English learning, more than $50 \%$ of them said they would love to try, and only $13.6 \%$ of them expressed disagree and strongly disagree with the statement. Further interview revealed that students with a negative attitude generally have a poor English ability, they don't have any interest in English learning, therefore no matter which teaching method has been adopted, there's not much impact on their English learning. 
Table 1. Students' understanding and acceptance of English teaching methods

\begin{tabular}{|l|c|c|}
\hline & \multicolumn{2}{|c|}{ Question } \\
\hline Options & You understand what is SET & You are willing to try SET for English learning \\
\hline Strongly Agree & $4.8 \%$ & $14.0 \%$ \\
\hline Agree & $18.9 \%$ & $42.1 \%$ \\
\hline General & $36.0 \%$ & $30.3 \%$ \\
\hline Disagree & $29.8 \%$ & $10.1 \%$ \\
\hline Strongly disagree & $10.5 \%$ & $3.5 \%$ \\
\hline
\end{tabular}

Teacher questionnaire. Figure 4 shows the survey results of teachers' understanding of SET, actually, most of them are familiar with it.

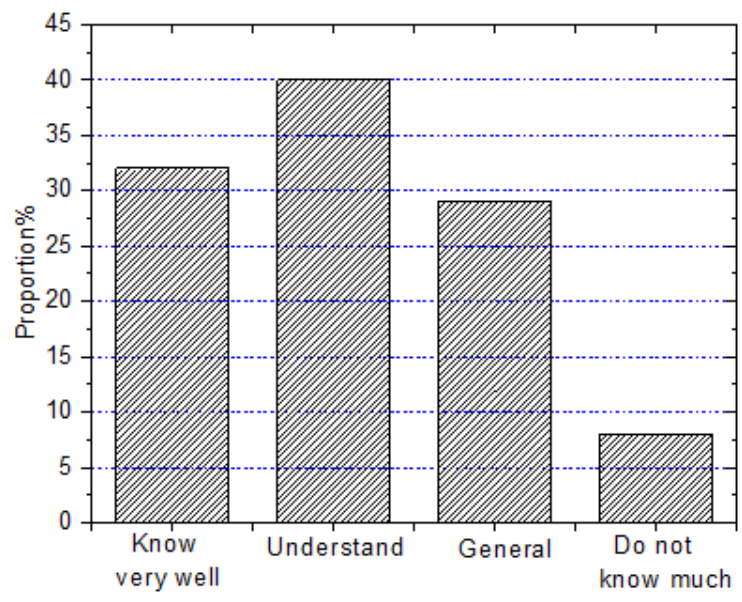

Fig. 4. Teachers' understanding of SET

Figure 5 gives the statistics on the teaching methods adopted by teachers during English teaching. Most teachers still apply the lecturing method in English teaching, further interview suggested that the teachers think the lecturing method is helpful for completing their teaching plans and teaching goals; although other teaching methods can improve students' learning ability and comprehensive English ability, due to limitations such as the exam-orientated education mode and the class hours, these methods are only used occasionally. As for the application of SET, the surveyed teachers said that they generally use multimedia such as images and videos to restore the language scenes. 


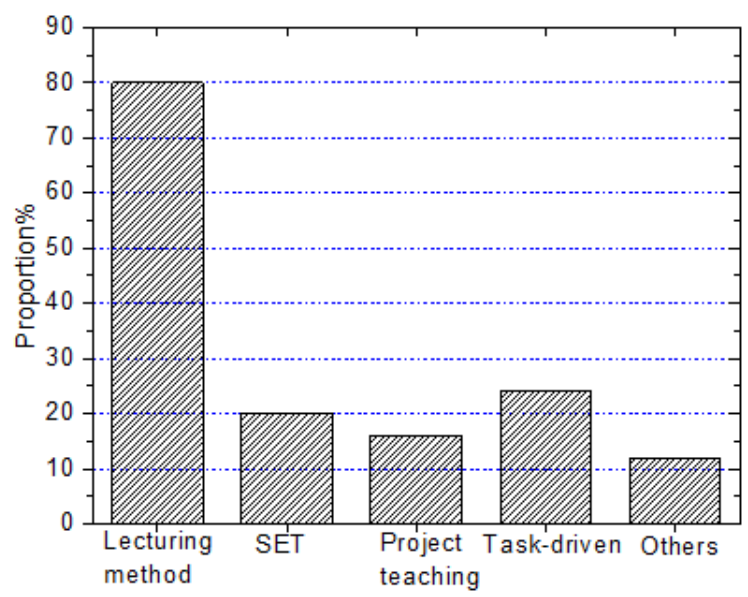

Fig. 5. Teaching methods adopted by teachers in English teaching

Through questionnaire results we can see that, now the college students' English proficiency is generally at a low level; the traditional teaching mode adopted by teachers only has an average effect on cultivating students' English ability; teachers have a good understanding of SET, and most students are willing to try SET in their English learning, all these indicate that it's of certain feasibility to apply SET in college English teaching.

\section{Effect and quality of SET}

\subsection{Teaching mode design based on SET}

The design. In English teaching, how to let students open their mouths and speak the English language has always been a difficult and key point. In SET, teachers can work with students and combine with the teaching content to decorate the classroom as the teaching scenes. Then, through teamwork, role play and other teaching methods, students can blend with the scenes to complete the relevant teaching content. Figure 6 shows the basic teaching mode based on SET [12].

Activities of teachers: in the SET-based mode, at first the teachers should analyze and know about the students' English levels, interests and hobbies, personality, and other basic information, determine the teaching goals of each lesson according to students' actual conditions and the specific teaching content, and design teaching scenes that fit the teaching content [13]. Of course, it's not that SET is suitable for all teaching content, so teachers need to adjust the teaching methods according to actual situations; for teaching content that is applicable for SET, teachers should make efforts to create teaching scenes that are related to students' daily life and learning, so as to trigger their interest in learning and connect English learning with their life [14]. After the scene creation is completed, teachers need to issue the learning tasks to 
students through network platforms such as WeChat group to facilitate them to prepare for the learning tasks. Later when it comes to the classroom teaching, teachers should also change the traditional lecturing mode, and give back the class to students after a simple introduction, teachers only need to timely comment and summarize the discussion of each learning group and their performance; then after the class is over, teachers need to give a summary and reflection of the SET implementation situations of this lesson, correct the existing problems in a timely manner, and constantly improve the SET-based mode [15].

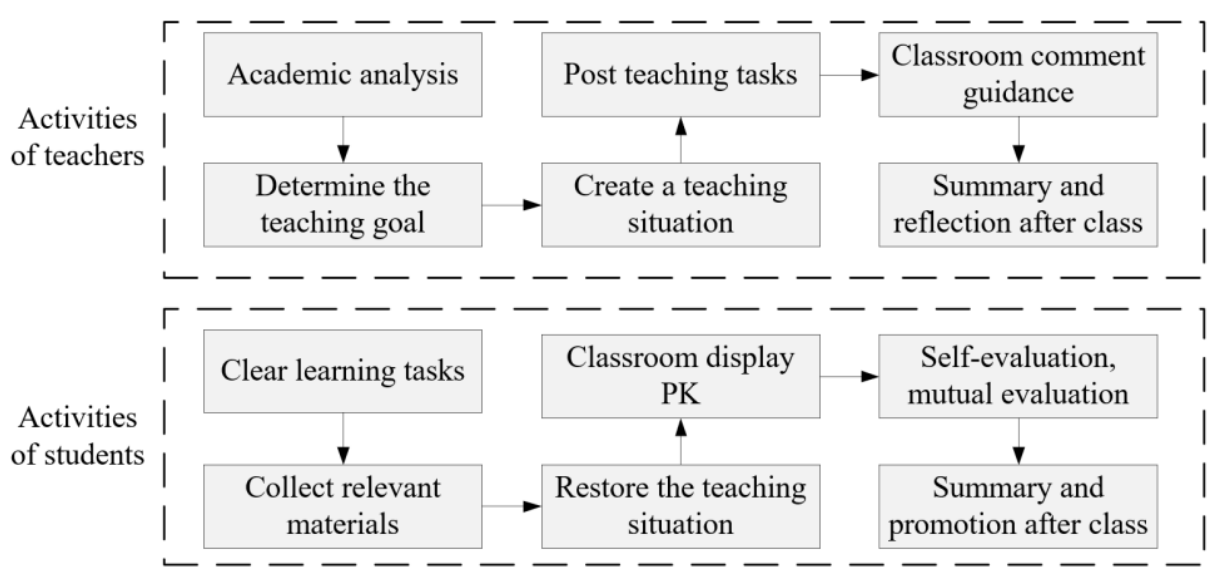

Fig. 6. The basic teaching mode based on SET

Activities of students: in the SET-based English teaching mode, students are the dominant party of the class, after receiving relevant learning tasks, they can adopt leaning methods such as self-researching or group-study, and collect data before the class via online searching or reading reference books based on the teaching tasks assigned by teachers or the learning scenes created, the collected data include the simple props required for scene creation by teachers or students, and the relevant vocabulary, grammar, and sentence patterns used in the scenes. Later in the class, students in each learning group restore the scenes according to the teaching content, and give demonstrations, after that, the learning groups will evaluate their own works and the performance of other learning groups, and learn from each other. After class, students conduct self-summary and reflection based on the demonstrations presented in the class, apply the knowledge they learnt in class to their real life, and improve their comprehensive English ability [16].

The teaching process. Figure 7 gives the teaching process of SET [17]. With the teaching of the unit course "Shopping" in college English as an example, here we give an analysis on the teaching process of SET: after the course teacher determines the teaching goals, the scenes in the textbooks are restored in the classroom, the room is decorated simply to simulate a shopping mall, and the relevant learning tasks are assigned; after receiving the learning tasks, each learning group first determines its topic, for instance, the topic might be cloth shopping, or food shopping, then students 
in the learning group split up the works and cooperate with each other, some play customers and some play sellers, they prepare simple props separately, collect shopping-related sentence patterns and vocabularies. Later in the class, the course teacher first introduces the new class using a simple introduction or multimedia materials, then students in each learning group restore the scene of the task topic in the classroom, divide works, exchange, discuss, practice the dialogue, and correct each other's mistakes in pronunciation or sentence pattern, during this process, teacher can give some guidance whenever necessary [18]. Afterwards, each learning group demonstrates its work, during this process, students can learn the pronunciation and sentence pattern from other learning groups' demonstrations, at the same time, they could correct their mistakes; through such group demonstration and competition, students' English skills could be improved; they can master English knowledge in actual scenes, and such forms are conductive to cultivating students' team work spirit and ability. By the end of group demonstration, students in each group conduct selfevaluation and mutual-evaluation, and the course teacher summarizes and comments on the demonstration works of each group, so as to deepen students' understanding of the knowledge, realize the internalization and sublimation of knowledge, and encourage students to practice after class [19].

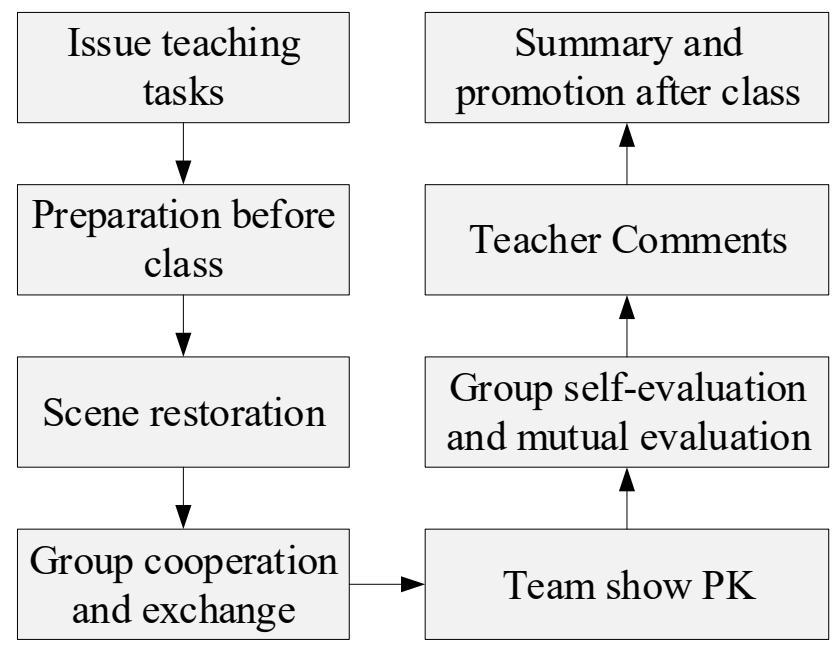

Fig. 7. Teaching process of SET

\subsection{Empirical test on the effect and quality of SET}

To verify the effectiveness of the SET-based teaching mode designed in this paper, several sophomore students in two classes of a Chinese college were taken as subjects to test the effect and quality of SET, there're 45 students in each class, and the two classes were taught by a same teacher, but respectively using the traditional teaching mode and the SET-based teaching mode, the test lasted for one semester. 
Figure 8 shows the English exam scores of students in the experimental class and the control class before the test. Figure 9 shows the English exam scores of students in the two classes after the test. According to the figure, before the test, there's not much difference in the scores of the two classes, while after the test, compared with the control class, the exam scores of the experimental class showed a great improvement.

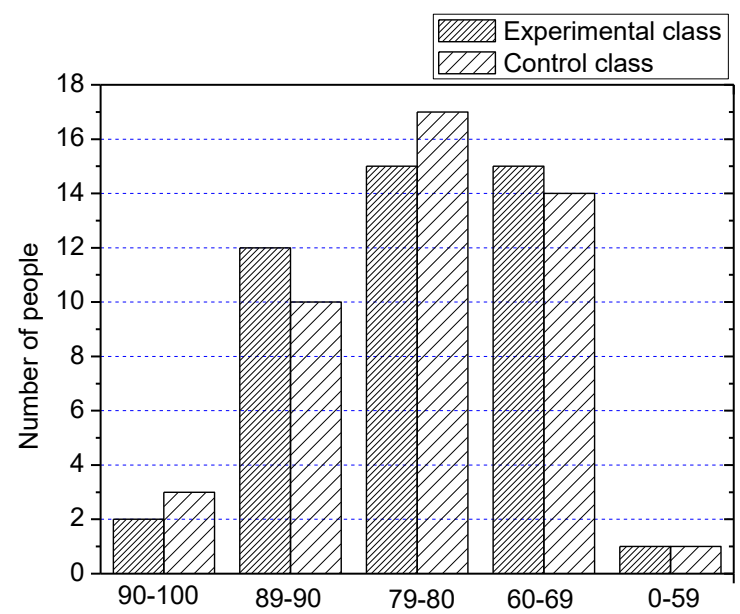

Fig. 8. English exam scores of experimental class and control class before the test

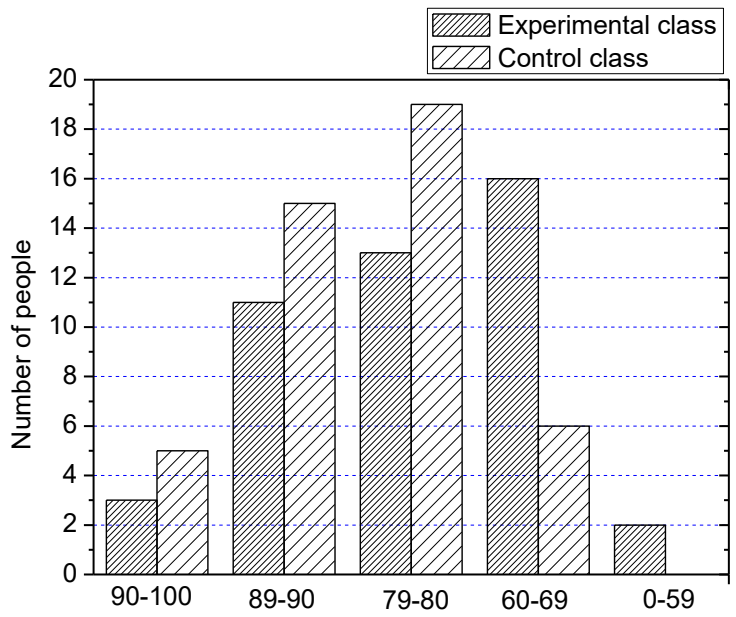

Fig. 9. English exam scores of experimental class and control class after the test

Figure 10 shows the survey results of students' satisfaction with the teaching methods and classroom atmosphere of English class before and after the test. As can be seen from the figure, there's no obvious change in the satisfaction of students in the two classes with the teaching methods and classroom atmosphere of English class 
before and after the test, and the satisfaction degree was not high. Before the test, there's not much difference in the satisfaction with teaching methods and classroom atmosphere of English class of students in the experimental class and in the control class; after the test, the satisfaction degree of students in the experimental class had improved significantly compared with that before the test and that of control class students, the proportion of students who were not so satisfied and dissatisfied dropped from $25.8 \%$ to $16.7 \%$, and the proportion of students who were very satisfied and satisfied increased from $26.8 \%$ to $44.7 \%$, indicating that most students approved of the SET mode.

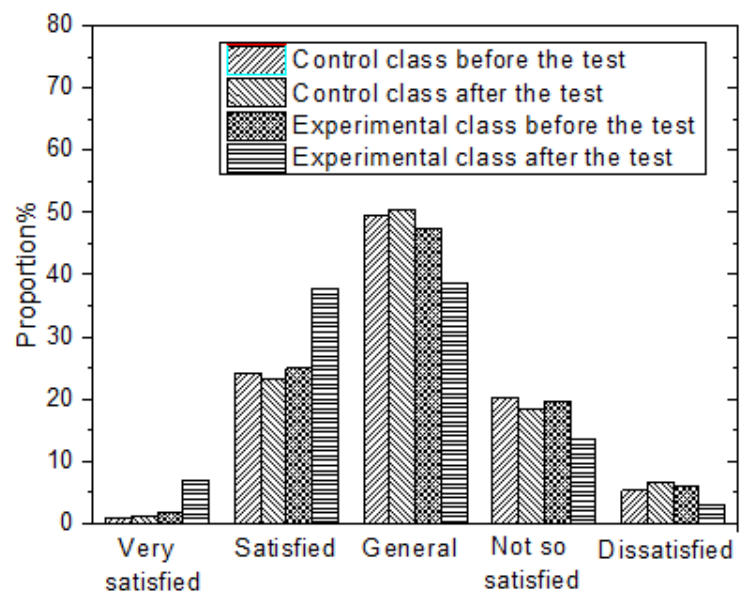

Fig. 10.Survey results of students' satisfaction with current English teaching methods and classroom atmosphere

Table 2 shows the attitude analysis of students in the experimental class towards SET, most student believe SET can trigger their learning interest and they are motived to participate in classroom teaching activities, the communication and exchange between teachers and students have been greatly promoted, and SET can improve their English proficiency.

Table 2. Students' attitudes toward SET

\begin{tabular}{|l|c|c|c|c|c|}
\hline & \multicolumn{4}{|c|}{ Options } \\
\hline Question & $\begin{array}{c}\text { Strongly } \\
\text { Agree }\end{array}$ & Agree & General & Disagree & $\begin{array}{c}\text { Strongly } \\
\text { disagree }\end{array}$ \\
\hline $\begin{array}{l}\text { SET can trigger learning interest and motivate you to } \\
\text { actively participate in classroom activities }\end{array}$ & $6.67 \%$ & $57.78 \%$ & $26.67 \%$ & $6.67 \%$ & $2.22 \%$ \\
\hline $\begin{array}{l}\text { SET can improve your comprehensive English } \\
\text { ability }\end{array}$ & $8.89 \%$ & $46.67 \%$ & $33.33 \%$ & $11.11 \%$ & $0 \%$ \\
\hline $\begin{array}{l}\text { SET can promote communication and exchange } \\
\text { between teachers and students }\end{array}$ & $5 \%$ & $24 \%$ & $14 \%$ & $2 \%$ & $0 \%$ \\
\hline
\end{tabular}


Figure 11 shows the survey results of teachers on whether they think the use of SET had achieved good teaching effect, and most of them believe SET had achieved better teaching effect.

Figure 12 shows the survey results of teachers on whether they think the use of SET had improved students' comprehensive English ability, and 68\% of them believe SET had significantly improved students' comprehensive English ability or improved it to a certain extent.

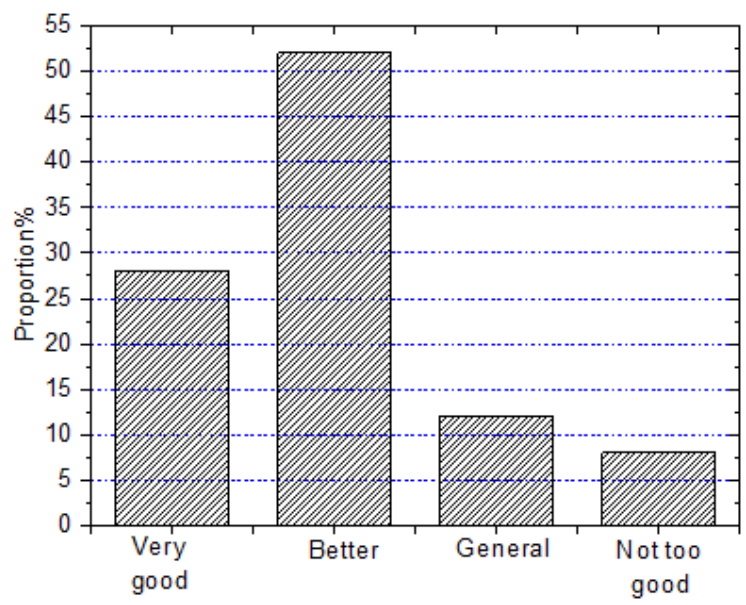

Fig. 11.Survey results of teachers on whether they think the use of SET had achieved good teaching effect

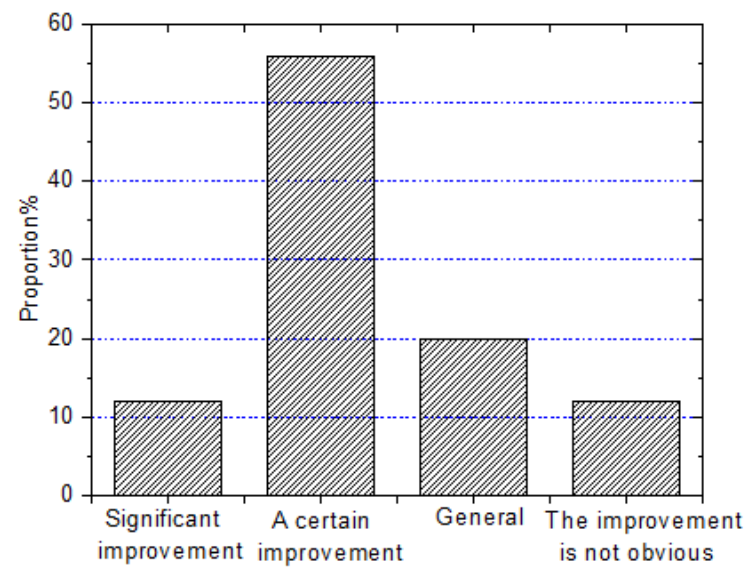

Fig. 12. Survey results of teachers on whether they think the use of SET had improved students' comprehensive English ability 


\section{Conclusions}

SET is more suitable for the actual learning requirements of English language, and it better conforms to students' cognition laws. This paper researched the effect and quality of SET and obtained the following conclusions:

1. Survey on the application of SET in current college English teaching revealed that college students' English proficiency is generally at a low level; the traditional teaching mode adopted by teachers only has an average effect on cultivating students' English ability, and it is feasible to apply SET in college English class.

2. This study designed a new English teaching mode based on SET, clarified the specific activities of teachers and students in teaching, and analyzed the specific teaching process based on the proposed SET-based new mode.

3. This study empirically tested the effect and quality of SET and the research results verified that SET can indeed trigger students' learning interest, enhance their comprehensive English ability, and improve the teaching quality of English class.

\section{$5 \quad$ References}

[1] Sun, H. (2020). The Learning Method of Peer Review in College English Writing Course, International Journal of Emerging Technologies in Learning, 15(5), 156-170. https://doi.org/10.3991/ijet.v15i05.13775

[2] Davis, L.K. (2010). Teaching and learning of English in secondary schools: A Zambian case study in improving quality by Chanda, Casmir. Modern Language Journal, 94(2): 357-358. https://doi.org/10.1111/j.1540-4781.2010.01039.x

[3] Castillo-Cuesta, L. (2020). Using Digital Games for Enhancing EFL Grammar and Vocabulary in Higher Education, International Journal of Emerging Technologies in Learning, 15(20), 116-129. https://doi.org/10.3991/ijet.v15i20.16159

[4] Settlage, J. (2011). Derek hodson: Teaching and learning about science: Language, theories, methods, history, traditions and value. Science \& Education, 20(3-4): 393-396. https://doi.org/10.1007/s11191-010-9266-7

[5] Kanzow, P., Wiegand, A. (2020). Teaching of composite restoration repair: trends and quality of teaching over the past 20 years. Journal of Dentistry, 95: 103303. https://doi.org/10.1016/j.jdent.2020.103303

[6] Kanzow, P., Wiegand, A., Wilson, N., Lynch, C.D., Blum, I.R. (2018). Contemporary teaching of restoration repair at dental schools in Germany - close to universality and consistency. Journal of Dentistry, 75: 121-124. https://doi.org/10.1016/j.jdent.2018.06.008

[7] Logtenberg, A., Boxtel, C.V., Hout-Wolters, B.V. (2011). Stimulating situational interest and student questioning through three types of historical introductory texts. European Journal of Psychology of Education, 26(2): 179-198. https://doi.org/10.1007/s10212-010$\underline{0041-6}$

[8] Pica, T. (2000). Tradition and transition in English language teaching methodology. System, 28(1), 1-18. https://doi.org/10.1016/s0346-251x(99)00057-3

[9] Taylor, P., Mcwilliam, E. (2013). Ragged edges: delivering quality tertiary teaching in post-colonial times. British Educational Research Journal, 21(5): 577-585. https://doi.org $\underline{10.1080 / 0141192950210503}$

[10] Brass, J. (2006). Methods of research on teaching the English language arts: the methodology chapters from the handbook of research on teaching the English language arts (2nd 
ed.). Studies in Second Language Acquisition, 28(4): 639-640. https://doi.org/10. $\underline{1017 / \mathrm{s} 0272263106250290}$

[11] Huang, A., Yang, S., Liaw, S.S. (2012). A study of user|"s acceptance on situational mashups in situational language teaching. British Journal of Educational Technology, 43(1): 52-61. https://doi.org/10.1111/j.1467-8535.2010.01152.x

[12] Kitchin, M.V. (1974). Some thoughts on situationalised teaching. English Language Teaching, 27(4): 292-296., 292-296. https://doi.org/10.1093/elt/xxviii.4.292

[13] Sandilos, L.E., Sims, W.A., Norwalk, K.E., Reddy, L.A. (2019). Converging on quality: Examining multiple measures of teaching effectiveness. Journal of School Psychology, 74: 10-28. https://doi.org/10.1016/i.jsp.2019.05.004

[14] Curriem, W.B. (2006). European syllabuses in English as a foreign language1. Language Learning, 25(2), 339-354. https://doi.org/10.1111/j.1467-1770.1975.tb00250.x

[15] Rings, L. (1992). Authentic spoken texts as examples of language variation: grammatical, situational, and cultural teaching models. IRAL - International Review of Applied Linguistics in Language Teaching, 30(1): 21-33. https://doi.org/10.1515/iral.1992.30.1.21

[16] Creemers, B., Kyriakides, L. (2009). Situational effects of the school factors included in the dynamic model of educational effectiveness. South African Journal of Education, 29(3): 293-315. https://doi.org/10.15700/saje.v29n3a270

[17] Vicente, S., Orrantia, J., Verschaffel, L. (2011). Influence of situational and conceptual rewording on word problem solving. British Journal of Educational Psychology, 77(Pt4): 829-848. https://doi.org/10.1348/000709907x178200

[18] Poole, M., Harman, E., Deden, A. (1998). Managing the quality of teaching in higher education institutions in the 21st century. Australian journal of education, 42(3): 271-284. https://doi.org/10.1177/000494419804200305

[19] Rahman, M.M., Pandian, A. (2018). A critical investigation of English language teaching in Bangladesh unfulfilled expectations after two decades of communicative language teaching. English Today, 34(3): 43-49. https://doi.org/10.1017/s026607841700061x

\section{$6 \quad$ Authors}

Kun Liang is a lecturer and working on Department of Public Foreign Languages of Shi jiazhuang University of Applied Technology, Hebei, China. She graduated from Hebei Normal University and the research interests is the teaching method of higher vocational. Since she got the lecturer, she has published more than eight papers and four books.

Yanan Hao is an associate professor working on English teaching in the School of Shijiazhuang University of Applied Technology, China. She graduated from the University of Waikato in New Zealand. She has been working in English teaching after graduation. Her research interests include Teaching Methods and Second Language Acquisition. She has conducted and participated in 5 research projects, and published 7 papers (Email: yananhao2021@126.com).

Jiangyong Zhao is an associate professor working in the Department of Public Foreign Language in Shijiazhuang University of Applied Technology, China. His research interests include English competitions and teaching methodology. Three papers are published and 3 text books are published (Email: monster6788@sina.com.cn).

Article submitted 2021-09-04. Resubmitted 2021-10-11. Final acceptance 2021-10-12. Final version published as submitted by the authors. 